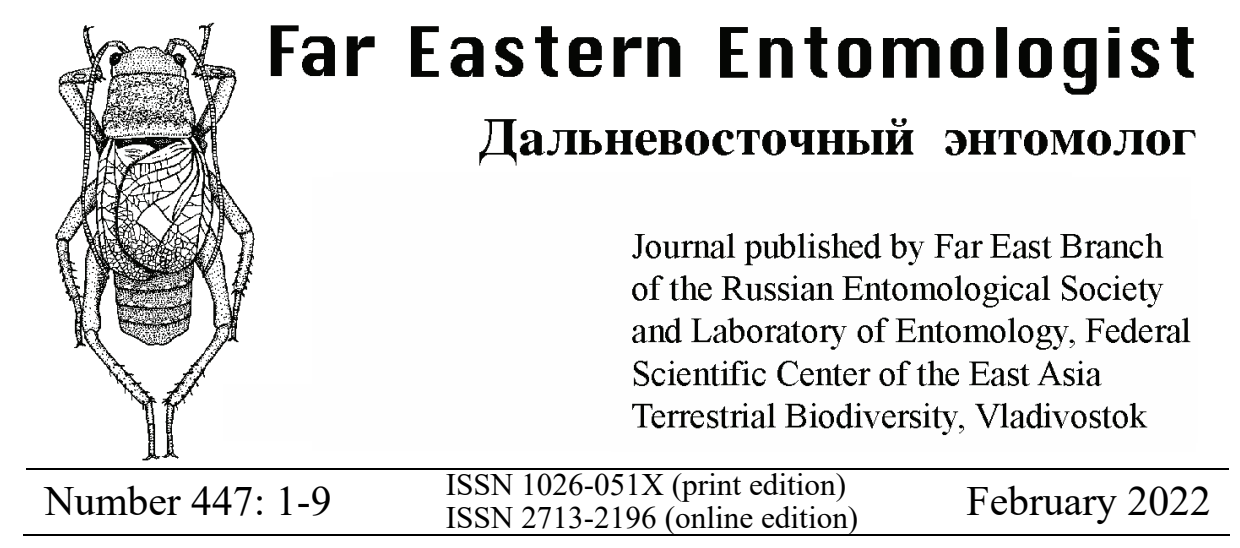

https://doi.org/10.25221/fee.447.1

http://zoobank.org/References/54DB7645-E600-43C9-A4CA-8188CB4C250A

\title{
A NEW GENUS OF THE SUBFAMILY LANGURIINAE (COLEOPTERA: EROTYLIDAE) FROM THE LATE EOCENE BALTIC AMBER
}

\author{
J. Kupryjanowicz ${ }^{1)}$, G. Yu. Lyubarsky ${ }^{2 *}$, E. E. Perkovsky ${ }^{3,4)}$
}

1) The Andrzej Myrcha University Natural Science Centre, University of Bialystok, K. Ciolkowskiego 1J, 15-245 Biatystok, Poland.E-mail: kuprzool@uwb.edu.pl

2) Zoological Museum of Moscow State University, Gerzen str. 2, Moscow, 105009, Russia.*Corresponding author,E-mail: lgeorgy@rambler.ru

3) Schmalhausen Institute of Zoology, NAS of Ukraine, B. Khmelnitskogo str. 15,Kiev,01030,Ukraine.E-mail: perkovsk@gmail.com

4) Paleontological Institute, RAS, Profsoyuznaya 123, Moscow, 117647, Russia.

Summary. Thallisellites olgae gen. et sp. n. (Erotylidae: Languriinae, Thallisellini) is described from the Late Eocene Baltic amber. Extant species of the tribe Thallisellini are all of a neotropical distribution. The new genus is similar to the extinct Serramorphus Lyubarsky et Perkovsky, 2017 from Bitterfeld amber. The new genus differs from Serramorphus by the smooth, rounded and not dentate lateral margin of the pronotum (in Serramorphus, the lateral margin is sinuous and spinose). New genus is considered monotypic and differs from extant genera of Thallisellini primarily in the strongly developed anterolateral angles of the pronotum. Family Tarsonemidae (Acari) is reported from the Baltic amber for the first time.

Key words: beetles, Cucujoidea, taxonomy, new taxa, Tarsonemidae, Europe.

Я. Куприянович, Г. Ю. Любарский, Е. Э. Перковский. Новый род подсемейства Languriinae (Coleoptera: Erotylidae) из балтийского янтаря // Дальневосточный энтомолог. 2022. N 000. С. 1-9. 
Резюме. Из позднеэоценового балтийского янтаря описан Thallisellites olgae gen. et sp. n. (Erotylidae: Languriinae, Thallisellini). Современные виды трибы Thallisellini имеют неотропическое распространение. Новый род наиболее близок к вымершему роду Serramorphus Lyubarsky et Perkovsky, 2017 из саксонского янтаря, но отличается от него гладким, округлым, без зубцов боковым краем переднеспинки (у Serramorphus боковой край волнистый, с зубцами). Новый монотипичный род отличается от современных родов трибы Thallisellini сильно развитыми передними углами переднеспинки. Клещи семейства Tarsonemidae впервые указаны из балтийского янтаря.

\section{INTRODUCTION}

The family of Erotylidae includes over 3500 species in 11 tribes and 6 subfamilies (Leschen \& Buckley, 2007; Leschen et al., 2010). In this work, we do not touch upon a subfamily Erotylinae, the geological history of which may constitute a separate study. In recent years, many extant and extinct genera have been erected in the other five subfamilies, i. e. extant Arrowcryptus Leschen et Węgrzynowicz, 2008, Cycadophila Xu et al., 2015, Ceratophila Tang et al., 2018, Tomolanguria Huang, 2020 and extinct Xenohimatium Lyubarsky et Perkovsky, 2012, Warnis Lyubarsky et al., 2016, Serramorphus Lyubarsky et Perkovsky, 2017, Xenophagus Lyubarsky et Perkovsky, 2017, Microzavaljus Lyubarsky et Perkovsky, 2018.

During our study, a new genus from Baltic amber was discovered. This genus is arranged to the family Erotylidae on base of the following characters: epimeron long, extending towards the third abdominal segment; first abdominal segment comparatively short, about 1.3 times as long as second abdominal segment; elytral punctures arranged into longitudinal rows.

The new genus is placed in the subfamily Languriinae and tribe Thallisellini based on the following characters: antennal insertion concealed in dorsal view; antennal club three-segmented; supraocular line not present; anterolateral angles of pronotum well developed; procoxal cavity open externally; tibial terminal spurs not present, tarsal shelf not present.

The tribe Thallisellini comprises extant genera, all Neotropical, Acryptophagus Grouvelle, 1919 (1 species), Platoberus Sharp, 1900 (10 species), Pseudhapalips Champion, 1913 (2 species), Thallisella Crotch, 1876 (13 species), and an extinct genus Serramorphus.

\section{MATERIAL AND METHODS}

The examined material (the holotype) will be deposited at the Andrzej Myrcha University Natural Science Centre at the University of Bialystok (Poland) (UCP UwB) with the collection number UCP UwB 1701.

Stacks of photographs were taken using a Nikon E-800 microscope, with $\times 4$ and $\times 10$ optics and an Olympus OM-D E-M10II digital camera. Brightfield and incident illumination were used. The stacks were corrected for colour, brightness, and noise using Adobe Lightroom software. The images were stacked using Helicon Focus 7 software. 


\section{TAXNOMY}

\section{Order Coleoptera}

Superfamily Cucujoidea Latreille, 1802

Family Erotylidae Latreille, 1802

Subfamily Languriinae Crotch, 1873

Tribe Thallisellini Sen Gupta, 1968

Genus Thallisellites Kupryjanowicz, Lyubarsky et Perkovsky, gen. n. http://zoobank.org/NomenclaturalActs/DC2A21D0-E24B-4DBA-819E-FEB7068158D2

Type species: Thallisellites olgae sp. n.

DIAGNOSIS. New genus appears similar to Serramorphus but readily differs in the structure of the lateral margin of the pronotum, which is smooth, rounded and not dentate compared to sinuous and spinose lateral margin of pronotum in Serramorphus.

Frontoclypeal suture present. Antennal insertion not exposed in dorsal view. Antenna with 11 antennomeres and three-segmented club. Supraocular line not present. Anterolateral angles of pronotum well developed, spine-shaped. Lateral margin of pronotum in dorsal view rounded, not dentate. Pronotal pits not present. Procoxal cavity open behind. Mesoventral process narrower than mesocoxa. Submesocoxal lines not present. Tarsi without lobes beneath. Tibial terminal spurs not present. Tarsal formula 5-5-5. Length of tarsomere 1 equal to tarsomere 2. Scutellum transverse. Elytral punctation striate. Elytra narrowly explanate. Humeral spine not present. Epipleuron complete, extending to apex of elytron. Femoral line not present.

DESCRIPTION. Body parallel-sided, elongate, narrow, dorsally with decumbent pubescence. Head with hemispherical compound eyes (Fig. 1). Compound eyes comparatively large, gently facetted. Supraocular line not present. Antenna with 11 antennomeres and three-segmented club. Frontoclypeal suture present. Antennal insertion concealed in dorsal view. Maxillary palpus trimerous, basal palpomere short and transverse, second palpomere rounded, same long as wide, third palpomere elongate, slightly curved (Fig. 1). Frons weakly convex in dorsal aspect, punctured. First antennomere longest, elongated (Figs 1, 4). Antennal furrows not present.

Pronotum transverse, barely narrower than elytra, without lateral teeth, covered with short pubescence. Anterolateral angles of pronotum strongly developed (Fig. $1,5)$. Dorsal punctures dense. Lateral margins not beaded, rounded in dorsal view, not serrate, smooth. Posterior margin with basal lobe, basal depression, and basal pits not present.

Prosternal process straight cropped at the top, extending beyond procoxae (Fig. 3). Procoxal cavity open externally. Width of mesoventral process narrower than mesocoxa. Mesocoxae separated by ca. $0.5-1.0$ times width of mesocoxa. Mesoventral 
process narrower than mesocoxa. Submesocoxal line not present. Submetacoxal lines not present. Longitudinal line of metasternum not present (Fig. 7). Pro-, meso-, and metasternum strongly and densely punctured (Fig. 7). Metasternal process broad, extending beyond posterior margin of mesocoxae.

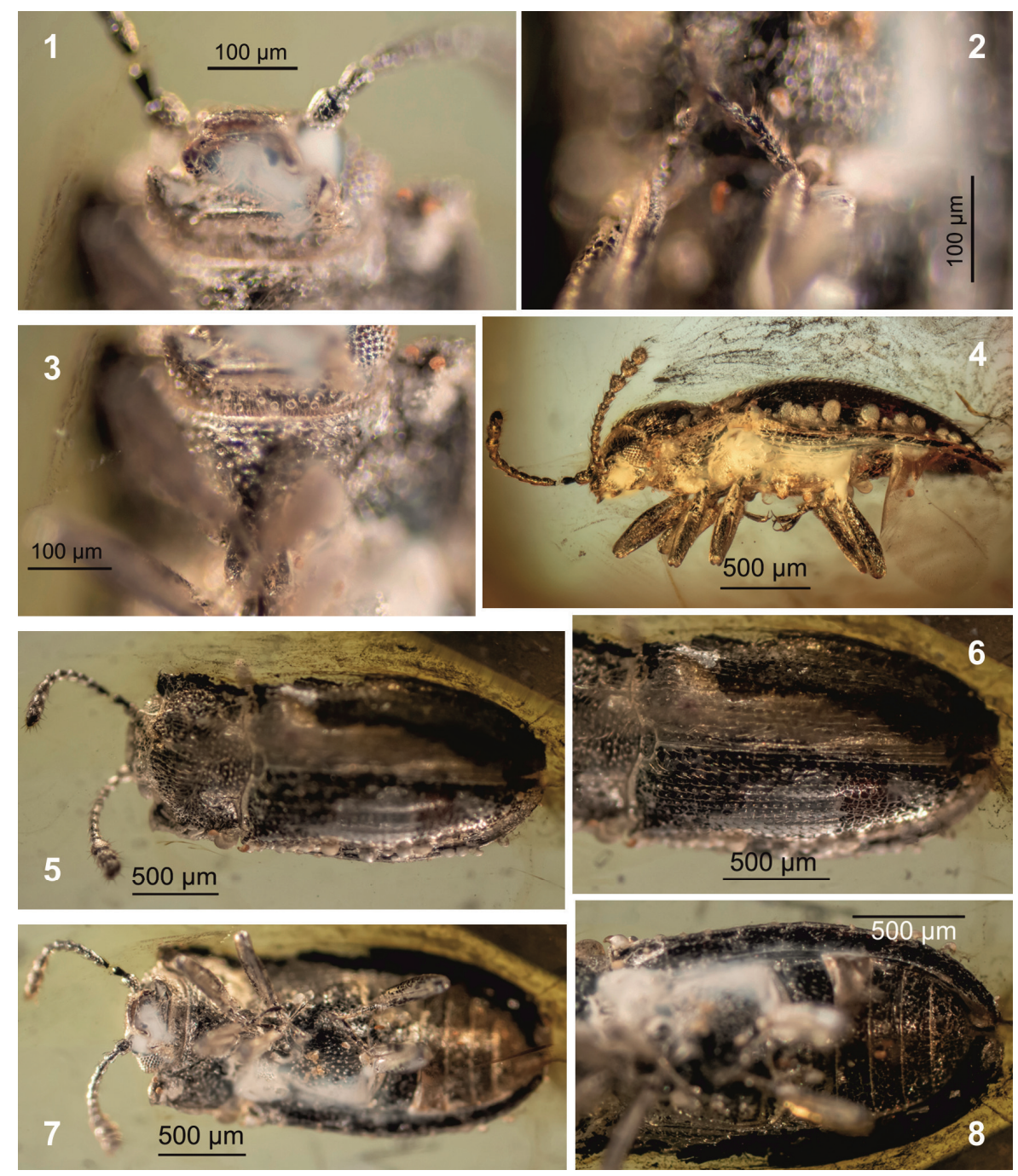

Figs 1-8. Photomicrographs of Thallisellites olgae sp. n., holotype, No UCP UwB 1701. 1 - head, ventral view; 2 - hind tarsi; 3 - thorax, ventral view; 4 - habitus, lateral view; 5 habitus, dorsal view; 6 - elytra, dorsal view; 7 - habitus, ventral view; 8 - abdomen, ventral view. 
Legs slender, tibia not dilated apically (Figs 2, 4). Apex of tibia crowned with several thickened setae. Tarsomeres slightly elongate. Pro-, meso- and metatibia apically not spinose. Tarsal formula 5-5-5. Tarsomeres not lobed. Tarsomere four not reduced. Tarsal claws not serrated.

Scutellar shield transverse, punctured. Humeral teeth at base of elytron not present. Elytral disc punctured, lateral margin of elytra slightly flattened and reflected in dorsal view (Fig. 6). Punctures of elytra moderately large, arranged into longitudinal rows. Ventrites weakly pubescent, irregularly punctured. Epipleuron extending towards apex of elytron (Fig. 8).

First abdominal ventrite slightly longer than width of second ventrite. Femoral lines not present.

ETYMOLOGY. Generic name is derived from the tribal name Thallisellini.

Thallisellites olgae Kupryjanowicz, Lyubarsky et Perkovsky, sp. n. http://zoobank.org/NomenclaturalActs/EAE8DDA7-969C-40A2-B4AD-75072FC501EA Figs 1-8

TYPE MATERIAL. Holotype: number UCP UwB 1701(UCP UwB), ex coll. Jonas Damzen JDC7010; Baltic amber, Late Eocene. Syninclusion: Acari, Tarsonemidae, cf. Tarsonemus, female.

DESCRIPTION. Body elongate-oval, length $2.3 \mathrm{~mm}$, maximum width $1.1 \mathrm{~mm}$, uniformly dark brown (Fig. 5). Head and pronotum shortly setose. Compound eye hemispherical. Length of compound eye equal to half head length. Facets small, approximately same diameter as head dorsal punctures. Dorsal punctures on head moderately large, intervening spaces narrower than puncture diameter. Antenna slender, antennomeres of flagellum elongate (Figs 4, 5). Antennal club weakly flattened. Basal antennomere slightly longer than and 0.3 as wide as antennomere two. Second antennomere slightly shorter than antennomere three. Third antennomere longer than antennomere four and equal to length of basal antennomere. Antennomeres two, four, five, and seven slightly elongated. Fifth antennomere longer than next one. Sixth antennomere shorter than antennomere seven. Eighth antennomere slightly transverse, wider than antennomere seven. Ninth antennomere as long as wide, penultimate antennomere slightly transverse, terminal antennomere elongate oval. Antenna long and extending beyond basal margin of pronotum.

Pronotum transverse, ratio of pronotal width to length 1.6. Anterior margin of pronotum slightly sinuous (Fig. 5). Anterolateral angles expanded, with acute spine that is curved posteriad. Extensions at the anterolateral angles without smooth face. Maximum width of pronotum across midlength. Lateral margins slightly converged apicad and posteriad, slightly expanded, slightly serrated, not beaded. Punctures moderately large, intervening spaces about as narrow as puncture diameter. Length of elytra 2.8 of pronotal length. Posterior margin sinuous, with large median lobe. Posterolateral angles right-angled, basal edge sinuous. Basal groove distinct, wide.

Tarsomeres one and two subcylindrical, tarsomeres three and four slightly widened beneath (Figs 2, 7). Tarsomeres 1-3 about same length, tarsomere half long 
as antennomere two or three, terminal tarsomere the longest but shorter than combined length of tarsomeres one to four.

Scutellar shield about 1.5 times wider than long, moderately strongly punctured. Punctures on elytra (Fig. 6) with intervening spaces about one puncture diameter; at least 14 rows of larger punctures on each elytron; intervals between punctures in row are narrower than their diameters. Elytra covered with short, pale setae arranged in longitudinal rows. Setae only slightly raised and slightly overlapping each other. Elytral seta about as long as length of tarsal claw.

Abdominal ventrites less strongly but rather densely punctured compared to metasternum (Fig. 8). Ventrites densely setose. Punctures on fifth ventrite similar like on others, even and rather dense, without thickened setae and impunctate areas.

ETYMOLOGY. Patronymic. The species is named after Olga Zolotarenko, the daughter of the third author.

\section{DISCUSSION}

The structure of the pronotum of Thallisellini exhibits of parallel variability with some genera of Cryptophagidae Kirby, 1837. In cryptophagids (Cryptophagini), the genera Paramecosoma Curtis, 1833 and Henotimorphus Lyubarsky, 1989 are specifically distinguished by the sinuous lateral margin of the pronotum from the genera Micrambe Thomson, 1863 and Cryptophagus Herbst, 1792, with a callosity on the anterolateral angles of pronotum, and a smooth lateral margin. The situation is similar among Thallisellini: Serramorphus from Bitterfeld amber is distinguished by the sinuous lateral margin of the pronotum, while Thallisellites gen. n. pronotum possesses a smooth, rounded lateral margin.

Thallisellites gen. $\mathrm{n}$. has the anterolateral angles of the pronotum provided with a curved, acute spine and, the lateral margin is smooth. Contrary, lateral margin is sinuous in Serramorphus.

Thallisellites gen. n. differs from extant genera of the tribe Thallisellini primarily in the strongly developed anterolateral angles of the pronotum.

The records of Thallisellini and of Neolitochropus Lyubarsky et Perkovsky, 2016 in Bitterfeld amber (Lyubarsky \& Perkovsky, 2016), were previously considered as examples of the tropical elements not present in the Baltic amber forest (Lyubarsky \& Perkovsky, 2017a, 2019).

Neolitochropus hoffeinsorum Lyubarsky et Perkovsky, 2016 was transferred to Cyclaxyridae; both extant cyclaxyrid species are known only from New Zealand. This species was widespread and abundant in Eocene Europe (in total, 13 specimens of it are known from across Rovno, Bitterfeld, and Baltic amber) (Gimmel et al., 2019; Gimmel \& Szawaryn, 2020), an additional species was described from Baltic amber recently (Háva, 2020). Besides, the cyclaxyrid genera Electroxyra et al., 2019 and Pacyclaxyra Tihelka et al., 2021 were described from Cenomanian Burmese amber (Tihelka et al., 2021). Extant cyclaxyrids are a part of the relict sooty mould community that is driven by scale insects from the subfamily Callipappinae (see Gavrilov-Zimin, 2018) the most ecologically important New Zealand herbivorous 
insects (Morales et al., 1988). These callipappines are known to produce copious honeydew, which supports fungal growth, which in turn hold up cyclaxyrids and two other endemic beetle families (Gimmel et al., 2019). Similar relict community in the Eocene amber forests should have depended on the equable Priabonian climate with warm winters, and not accidentally the first fossil cyclaxyrid was described from Rovno and Bitterfeld amber.

The new genus of Thallisellini described in the present paper is the first documented evidence of presence of the subfamily Languriinae in Priabonian Russoscandia (Ivanov et al., 2016). At the same time, the legal mining of Bitterfeld amber was extremely limited in comparison with Samland (Baltic amber), so languriines could to be much more common on the southern coast of Subparathetys than in the Baltic amber forest, i. e. Serramorphus rasnitsyni Lyubarsky et Perkovsky, 2017 appears only the fifteenth beetle species reported from Bitterfeld; e. g. cosmopolitan subfamily Xenoscelinae is represented by two genera in Baltic amber (Lyubarsky et al., 2016; Lyubarsky \& Perkovsky, 2017b) versus one genus in Bitterfeld (Lyubarsky \& Perkovsky, 2018); in Rovno amber xenoscelines are represented by monotypic genus (Lyubarsky \& Perkovsky, 2012) as well.

Thus, our new finding does not affect the overall picture of the high abundance of tropical elements in the Bitterfeld and Rovno amber forests versus Baltic amber forest as predicted by Wolfe et al. (2016) and Mänd et al. (2018), and supported faunistically not only by assessment of the amber faunas of ants, bethylids and biting midges (Perkovsky, 2016, 2017, 2018; Radchenko \& Perkovsky, 2021; Colombo et al., 2021c), but also newly unveiled, abundant Rovno amber records of the thermophile beetles, hymenopterans and termites (Legalov et al., 2018; Perkovsky et al., 2020; Sokolov \& Perkovsky, 2020; Colombo et al., 2021 a, b; Perkovsky \& Nel, 2021; Matalin et al., 2021, Yamamoto et al., 2022).

\section{ACKNOWLEDGMENTS}

We are grateful to D.D. Vorontsov (Koltzov Institute of Developmental Biology of the Russian Academy of Sciences, Moscow) for help with cutting the amber piece and for digital images, to A.A. Khaustov (Tyumen State University) and E.E. Lindquist (Canadian National Collection of Insects, Arachnids, and Nematodes, Ottawa, Canada) for mite determination. We are obliged to D. Telnov (Natural History Museum, London, United Kingdom) for proofreading the manuscript. The work of the second co-author has been supported by a grant from the Zoological Museum AAAA A16-116021660077-3.

\section{REFERENCES}

Colombo, W.D., Perkovsky, E.E. \& Azevedo, C.O. 2021a. Synopsis of the fossil Pristocerinae (Hymenoptera, Bethylidae), with description of two new genera and six species from Burmese, Taimyr, Baltic and Rovno ambers. Historical Biology, 33(9): 1736-1752. DOI: $10.1080 / 08912963.2020 .1733551$ 
Colombo, W.D., Perkovsky, E.E., Waichert, C. \& Azevedo, C.O. 2021b. Synopsis of the fossil flat wasps Epyrinae (Hymenoptera, Bethylidae), with description of three new genera and 10 new species. Journal of Systematic Palaeontology, 19(1): 39-89. DOI: 10.1080/14772019.2021.1882593

Colombo, W.D., Perkovsky, E.E. \& Vasilenko, D.V. 2021c. The first sclerodermine flat wasp (Hymenoptera: Bethylidae) from upper Eocene Rovno amber, Ukraine. Alcheringa, 45(4): 429-434, DOI: 10.1080/03115518.2021.2006311

Gavrilov-Zimin, I.A. 2018. Ontogenesis, morphology and higher classification of archaeococcids (Homoptera: Coccinea: Orthezioidea). Zoosystematica Rossica, Supplementum, 2018: 1-264. DOI: 10.31610/zsr/2018.supl.2.1

Gimmel, M.L. \& Szawaryn, K. 2020. A new genus-level and two new species-level synonyms in the extinct genus Neolitochropus Lyubarsky \& Perkovsky (Coleoptera: Cyclaxyridae). Zootaxa, 4894(4): 598-599. DOI: 10.11646//zootaxa.4894.4.7

Gimmel, M.L., Szawaryn, K., Cai, C. \& Leschen, R.A.B. 2019. Mesozoic sooty mould beetles as living relicts in New Zealand. Proceedings of the Royal Society Biological Sciences Series B, 286, 20192176 (7 pp.). DOI: 10.1098/rspb.2019.2176

Háva, J. 2020. A new species of Neolitochropus Lyubarsky \& Perkovsky, 2016 from Eocene Baltic amber (Coleoptera: Cucujoidea: Cyclaxyridae). Studies and Reports Taxonomical Series, 16(2): 343-346.

Ivanov, V.D., Melnitsky, S.I. \& Perkovsky, E.E. 2016. Caddisflies from Cenozoic resins of Europe. Paleontologicheskii Zhurnal, 2016(5): 53-61. [In Russian; English translation: Paleontological Journal, 50(5): 485-493].

Kupryjanowicz, J., Lyubarsky, G.Yu. \& Perkovsky, E.E. 2019. New species of family Smicripidae (Coleoptera: Cucujoidea) from Rovno amber. Paleontologicheskii Zhurnal, 2019(2): 55-59. [In Russian; English translation: Paleontological Journal, 53(2): 165-171].

Legalov, A.A., Nazarenko, V.Y. \& Perkovsky, E.E. 2018. A new genus of fungus weevils (Coleoptera: Anthribidae) in Rovno amber. Fossil Record, 21: 207-212. DOI: 10.5194/ fr-21-207-2018

Leschen, R.A.B. \& Buckley, T.R. 2007. Multistate characters and diet shifts: Evolution of Erotylidae (Coleoptera). Systematic Biology, 56(1): 97-112. DOI: 10.1080/ 10635150701211844

Leschen, R.A.B., Skelley, P.E. \& McHugh, J.V. 2010. Erotylidae Leach. 1815. P. 311-319. In: Leschen, R.A.B., Beutel, R.G. \& Lawrence, J.F. (Eds.), Handbook of Zoology, Coleoptera, Beetles. Vol. 2. Morphology and Systematics (Elateroidea, Bostrichiformia, Cucujiformia partim). Walter de Gruyter, Berlin/New York. DOI: 10.1515/9783110911213.311

Lyubarsky, G.Yu. \& Perkovsky, E.E. 2012. A new genus of Erotylidae from Eocene amber (Coleoptera: Clavicornia). Russian Entomological Journal, 21(1): 35-38.

Lyubarsky, G.Yu. \& Perkovsky, E.E. 2016. A new genus, Neolitochropus (Coleoptera: Cucujoidea: Phalacridae), from the Upper Eocene Bitterfeld amber. Russian Entomological Journal, 25(3): 249-253. DOI: 10.15298/rusentj.25.3.04

Lyubarsky, G.Yu. \& Perkovsky, E.E. 2017a. Serramorphus, a new genus of Erotylidae from Eocene amber (Coleoptera: Clavicornia) from Late Eocene Bitterfeldian amber. Russian Entomological Journal, 26(1): 37-40. DOI: 10.15298/rusentj.26.1.04

Lyubarsky, G.Yu. \& Perkovsky, E.E. 2017b. Xenophagus, a new genus of pleasing fungus beetles (Coleoptera: Erotylidae) from Baltic Amber. Russian Entomological Journal, 26(2): 147-150.

Lyubarsky, G.Yu. \& Perkovsky, E.E. 2018. Microzavaljus, a second extinct genus of pleasing fungus beetles (Coleoptera: Erotylidae) from Bitterfeld Amber. Russian Entomological Journal, 27(3): 271-276. DOI: 10.15298/rusentj.27.3.05 
Lyubarsky, G.Yu. \& Perkovsky, E.E. 2019. First species of Ephistemus (Coleoptera: Clavicornia: Cryptophagidae) from Baltic amber. Russian Entomological Journal, 28(1): 54 57. DOI: $10.15298 /$ rusentj.28.1.07

Lyubarsky, G.Yu., Perkovsky, E.E. \& Alekseev, V.I. 2016. The first record of the subfamily Xenoscelinae (Coleoptera, Erotylidae) from the Baltic amber. Paleontological Journal. 50(9): 963-969. DOI: 10.1134/S0031030116090070

Mänd, K., Muehlenbachs, K., McKellar, R.C., Wolfe, A.P. \& Konhauser, K. 2018. Distinct origins for Rovno and Baltic ambers: Evidence from carbon and hydrogen stable isotopes. Palaeogeography Palaeoclimatology, Palaeoecology, 505: 265-273. DOI: 10.1016/ j.palaeo.2018.06.004

Matalin, A.V., Perkovsky, E.E. \& Vasilenko, D.V. 2021. First record of tiger beetles (Coleoptera, Cicindelidae) from Rovno amber with the description of a new genus and species. Zootaxa, 5016(2): 243-256. DOI: 10.11646/zootaxa.5016.2.5

Morales, C.F., Hill, M.G. \& Walker, A.K. 1988. Life history of the sooty beech scale (Ultracoelostoma assimile) (Maskell) (Hemiptera: Margarodidae) in New Zealand Nothofagus forests. New Zealand Entomologist, 11: 24-37. DOI: 10.1080/00779962.1988.9722532

Perkovsky, E.E. 2016. Tropical and Holarctic ants in Late Eocene ambers. Vestnik zoologii, 50(2): 111-122. DOI: 10.1515/vzoo-2016-0014

Perkovsky, E.E. 2017. Comparison of biting midges of the early Eocene Cambay amber (India) and late Eocene European ambers supports the independent origin of European ambers. Vestnik zoologii, 51(4): 275-284. DOI: 10.1515/vzoo-2017-0033

Perkovsky, E.E. 2018. Only a half of species of Hymenoptera in Rovno amber is common with Baltic amber. Vestnik zoologii, 52(5): 353-360. DOI: 10.2478/vzoo-2018-0037

Perkovsky, E.E. \& Nel, A. 2021. A new Rovno amber termite genus (Isoptera, Rhinotermitidae) from Styr river basin. Palaeontologia Electronica, 24(1), a05. DOI: $10.26879 / 1127$

Perkovsky, E.E., Olmi, M., Vasilenko, D.V., Capradossi, L. \& Guglielmino, A. 2020. First Bocchus Ashmead (Hymenoptera: Dryinidae) from Upper Eocene Rovno amber: $B$. schmalhauseni sp. nov. Zootaxa, 4819(3): 544-556. DOI: 10.11646/zootaxa.4819.3.6

Perkovsky, E.E., Zosimovich, V.Yu. \& Vlaskin, A.P. 2010. Rovno amber. P. 116-136. In: Penney, D. (Ed.). Biodiversity of Fossils in Amber from the Major World Deposits. Siri Scientific Press, Manchester.

Radchenko, A.G. \& Perkovsky, E.E. 2021. Wheeler's dilemma revisited: first OecophyllaLasius syninclusion and other ant syninclusions in the Bitterfeld amber (late Eocene). Invertebrate Zoology, 18(1): 47-65. DOI: 10.15298/invertzool.18.1.05

Sokolov, A.V. \& Perkovsky, E.E. 2020. The first Eocene species of Bacanius (Coleoptera: Histeridae: Dendrophilinae) from Rovno amber. Russian Entomological Journal, 29(2): 157-160. DOI: 10.15298/rusentj.29.2.06

Tihelka, E., Huang, D. \& Cai, C. 2021. A new genus of giant sooty mould beetles from midCretaceous Burmese amber (Coleoptera: Cyclaxyridae). Cretaceous Research, 125, 104876. DOI: $10.1016 /$ j.cretres.2021.104876

Wolfe, A.P., McKellar, R.C., Tappert, R., Sodhi, R.N.S. \& Muehlenbachs, K. 2016. Bitterfeld amber is not Baltic amber: three geochemical tests and further constraints on the botanical affinities of succinite. Review of Palaeobotany and Palynology, 225: 21-32. DOI: 10.1016/j.revpalbo.2015.11.002

Yamamoto, S., Nazarenko, V.Y., Vasilenko, D.V. \& Perkovsky, E.E. 2022. First fossil species of ship-timber beetles (Coleoptera: Lymexylidae) from Eocene Rovno amber (Ukraine). Fossil Record. (in press) 